\title{
From the religious a priori to intending the absolute: Reflections on the methodological principles in Otto and Tillich against the backdrop of their historical problematic
}

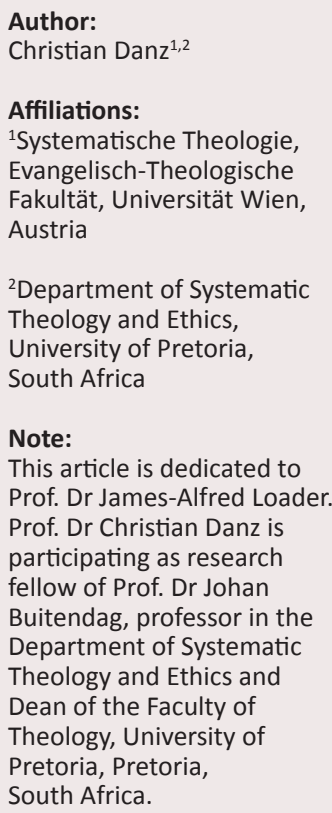

${ }^{2}$ Department of Systematic Theology and Ethics, University of Pretoria, South Africa

\section{Note:}

This article is dedicated to Prof. Dr James-Alfred Loader Prof. Dr Christian Danz is participating as research fellow of Prof. Dr Johan Buitendag, professor in the Department of Systematic Theology and Ethics and Dean of the Faculty of Theology, University of Pretoria, Pretoria, South Africa.

Article republished with updated side bar information.

\section{Correspondence to:} Christian Danz

Email:

christian.danz@univie.ac.at

\section{Postal address:}

Evangelisch-Theologische Fakultät, Universität Wien, Schenkenstraße 8-10 A-1010 Wien

Dates:

Received: 03 Apr. 2013 Accepted: 31 May 2013 Published: 23 Aug. 2013 Republished: 08 Nov. 2013

How to cite this article: Danz, C., 2013, 'From the religious a priori to intending the absolute: Reflections on the methodological principles in Otto and Tillich against the backdrop of their historical problematic', HTS Teologiese Studies/ Theological Studies 69(1), Art. \#1980, 7 pages. http:// dx.doi.org/10.4102/hts. v69i1.1980

\section{Read online:}

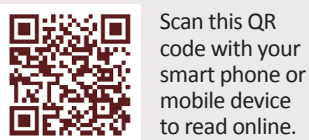

This contribution examines Rudolf Otto's and Paul Tillich's theories of religion against the background of the debates around 1900. Beginning with Wilhelm Windelband's motifs and Ernst Troeltsch's philosophies of religion, it is shown that Otto and Tillich alike elaborate on a performance-bound conception of religion from transcendental-philosophical and phenomenological motifs. Tillich, following Edmund Husserl, ultimately resolves the idea of a religious a priori as a concept of religion elaborated in terms of the theory of intentionality.

\section{Introduction}

Durch H[eidegger] und O[xner] (ich weiß nicht mehr, wer hier den Vortritt hat) wurde ich im letzten Sommer auf Ihr Buch über das Heilige aufmerksam und es hat stark auf mich gewirkt, wie kaum ein anderes Buch seit Jahren. Gestatten Sie, daß ich meinen Eindruck so fasse: Es ist ein erster Anfang für eine Phänomenologie des Religiösen, mindestens nach all dem, was eben nicht über eine reine Description und Analyse der Phänomene selbst hinausgeht. ${ }^{1}$ (Schütte 1969:141)

With these words written on 05 March 1919, Edmund Husserl described to his former Göttingen colleague, Rudolph Otto, the impression which his reading of the latter's work, Das Heilige, made upon him. Despite the critique which Husserl expresses about Otto's book, it will nevertheless:

in der Geschichte der echten Religionsphilosophie bzw. der Religionsphänomenologie eine bleibende Stelle behalten. Es ist ein Anfang und geht das ist sein Sinn auf die 'Anfänge', 'Ursprünge' zurück, es ist im schönsten Wortverstande 'originell'. (Schütte 1969:142)

Whoever brought Otto's book to Husserl's attention, we know - from the 60th volume of the collected works of Martin Heidegger, published in 1995 and entitled Phänomenologie des religiösen Lebens - that Heidegger not only worked on a discussion of Das Heilige, but also undertook a phenomenology of the religious (Heidegger 1995a, 1995b). Furthermore, to be found amongst the drafts and outlines of a lecture on Die philosophischen Grundlagen der mittelalterlichen Mystik, planned for the winter semester of 1918-1919, is the groundwork of a review of Otto's work (Heidegger 1995b:332-334). Heidegger's notes on Otto, his outlines for the planned lecture, and above all his own lecture from the winter semester of 1920-1921, Einleitung in die Phänomenologie der Religion, indicate the scope of the problems which characterise Otto's work. ${ }^{2}$ In the debates concerning the concept of religion, this may be seen as being between neo-Kantianism and Phenomenology, against the backdrop of the debates concerning the absoluteness of Christianity. ${ }^{3}$ The establishment of the validity of religion in a religious a priori was increasingly perceived as being problematic. Such a conception not only raises the question as to how religion is to be classified within the structure of consciousness - with it's necessarily realised a priori functions of consciousness - but also that of its relation to the other functions of consciousness. Furthermore, the a priori functions of consciousness are necessarily realised. Yet, if this is the case, how are the underivability and contingency which are constitutive for religion, to be understood? Against the background of the problems indicated here, it is no wonder that in the contemporary controversies, the attempt was made cum grano salis to carry neo-Kantian conceptions forward - by incorporating phenomenological motifs - toward a performance-bound theory of religion. Into this context, Heidegger's early phenomenology of religion seamlessly assimilates itself. ${ }^{4}$

1.Edmund Husserl to Rudolph Otto, from 5.3.1919 (Rudolf-Otto-Posthumous Works, University Library of Marburg, Hs 797:794), in Schütte (1969:141).

2.Concerning Heidegger's early philosophy of religion cf. Danz (2009:325-341).

3.Cf. only Heim (1920:14-41). On the debate concerning the philosophy of religion around $1900 \mathrm{cf}$. Pfleiderer (1992).

4.Cf. Heidegger (1995a:334) 'Windelband ("Das Heilige") [1921] zeigt den Einblick in fast dieselbe Fülle religiöser Phänomene, wenn auch in stark rationaler Formulierung, zeigt aber vor allem, daß entscheidend ist dies Prinzip der Problemstellung überhaupt und davon abhängig die Gliederung der Problemgruppen und die methodischen Ansätze!

Copyright: (C) 2013. The Authors. Licensee: AOSIS OpenJournals. This work is licensed under the Creative Commons Attribution License. 
Heidegger did away with establishing the validity of religion as a religious a priori, and replaced it with a determination of religion as the reflexive transparency and expression of actual life (cf. Heidegger 1995:105).

If the following is to deal with the methodological groundwork of Rudolph Otto's and Paul Tillich's theories of religion, then the above indicated historical problem ought also to be included. Thus, I would like to begin with a short glance at the theories of religion and methodological groundwork of Wilhelm Windelband and Ernst Troeltsch. The transcendental explanations of religion in the structure of human consciousness, which were propounded by Troeltsch as well as Windelband, make up the background of Otto's and Tillich's theories of religion. In a second course of deliberation, Otto's theory of religion is to be mapped out against the background of the previously introduced historical problem and discussed with an eye to its thematic history. Like Otto, the young Tillich strives to work out a theory of religion in which transcendental and phenomenological motifs are connected. The third part of this article will deal with Tillich's program concerning the theory of religion and its structural elements.

\section{From the Holy to the religious a priori, or: The place of religion within the structure of human consciousness}

In 1902 Wilhelm Windelband, a neo-Kantian from Heidelberg, put forward an outline of the philosophy of religion which was concerned with a transcendental groundwork of religion within the structure of human consciousness. It is according to this way of construing the problem that Windelband (1921) describes the task of the philosophy of religion. This task consists of:

die Stellung aufzuweisen, welche die Religion in dem zweckvollen Zusammenhange der Funktionen des vernünftigen Bewußtseins einnimmt, und von da aus alle ihre einzelnen Lebensäußerungen zu verstehen und zu bewerten. (p. 295)

A philosophy of religion which is committed to the methodological insights of critical idealism has the task of determining the place and function of religion within the structure of consciousness. In terms of a theory of validity, religion is founded when a function to which religion can be traced becomes nameable within the interior structure of consciousness. In the first part of his essay Windelband undertook just such transcendental groundwork, whilst dedicating the second part to a formal theory of the categories of religious consciousness. In the following, I will limit myself to Windelband's transcendental groundwork.

The point of departure of Windelband's transcendental theory of religion is made up of the necessary a priori functions of consciousness: thought, action, and feeling, which correspond to the three sciences, logic, ethics and aesthetics. It is by means of these necessary a priori functions of consciousness, that culture is constituted. ${ }^{5}$ The question thereby arises to which of these three functions religion is to be assigned. Windelband's answer, which is significant for the debate of the philosophy of religion around 1900, is that religion indeed constitutes a separate cultural force, but is distinct from the three functions of consciousness. ${ }^{6}$ Thus, Windelband classifies religion within the transcendental structure of consciousness in such a way that it is neither linked to one of the three culture functions, nor does it in and of itself constitute a separate function of consciousness. Nevertheless, religion must have a 'rational cause' (Windelband 1910-1911:193, 299) and must correlate with the culture functions. Otherwise, not only would the unity of consciousness be abolished, but the contribution which religion makes to modern culture would also no longer be evident. Windelband accomplishes this task by referring religion to a problem which arises in each of the three culture functions, but which cannot be dealt with in any of them. 'Dies' says Windelband (1921:300) 'kann aber nichts anderes sein, als jene Antinomie des Bewußtseins, welche in dem Verhältnis zwischen dem Sollen und dem Müssen, zwischen den Normen und den Naturgesetzen zutage tritt.' For Windelband, the reference point of religion is an antinomy of consciousness, namely, the tension between ideal validity and empirical facticity. And this antinomy appears in all three functions of consciousness. However, the question as to wherein Windelband sees the essence of religion is not thereby answered.

'Religion', according to Windelband's basic determination 'ist transzendentes Leben; das Wesentliche an ihr ist das Hinausleben über die Erfahrung, das Bewußtsein der Zugehörigkeit zu einer Welt geistiger Werte, das Sichnichtgenügenlassen am empirisch Wirklichen' (Windelband 1921:305).

Windelband understands religion as the contingent becoming aware of the transcendental sphere of validity in terms of its dimension of unity and totality, or as he himself says, as the 'normal consciousness' which is already engaged in the three necessary, a priori culture functions of consciousness. ${ }^{7}$ Of course, this cannot take place except in the culture functions of consciousness, where it nevertheless must not be thought to seamlessly collapse into them. For Windelband, religion represents the unity of culture, or respectively, the unity of the three culture functions thought, action, and feeling, which cannot be grasped through those functions themselves. ${ }^{8}$

5.Cf. Windelband (1910-1911:191): 'Denn unter Kultur verstehen wir schließlich doch nichts anderes, als die Gesamtheit dessen, was das menschliche Bewußtsein vermöge seiner vernünftigen Bestimmtheit aus dem Gegebenen herausarbeitet: und den seiner vernunftigen Bestimmtheit aus dem Gegebenen herausarbeitet: und den
Springpunkt der Transzendentalphilosophie bildet Kants Einsicht, daß schon in dem, Springpunkt der Transzendentalphilosophie bildet Kants Einsicht, daß schon in dem,
was wir als gegeben hinzunehmen gewöhnt sind, sobald es als allgemeingültige was wir als gegeben hinzunehmen gewöhnt sind, sobald es als allgemeingültige
Erfahrung sich darstellt, eine Synthesis nach den Gesetzen des "Bewußtseins überhaupt", nach übergreifenden, sachlich gültigen Vernunftformen vorliegt.'

6.Cf. Windelband (1921:297): 'Daraus folgt, daß die Religionsphilosophie bei keiner von den drei philosophischen Grunddisziplinen allein untergebracht werden, daß sie nicht als Teil oder Anhang der Logik oder der Ethik oder der Ästhetik behandelt werden kann' (cf. also Windelband 1910-1911:192f.).

7.Windelband (1921:305): 'So ist also das Heilige inhaltlich nicht anders zu bestimmen als durch den Inbegriff der Normen, die das logische, ethische und ästhetische Leben beherrschen. [...] Heilig aber sind sie uns deshalb, weil sie nicht Produkte des einzelnen Seelenlebens, auch nicht Erzeugnisse des empirischen Gesellschaftsbewußtsein sind, sondern Wertinhalte einer höheren Vernunftwirklichkeit, an der uns teilzuhaben, die in uns zu erleben uns vergönnt ist.'

8.Cf. Windelband (1910/11:193): 'Ihre besonderen Funktionen soweit sie ihre Vernunftgründe aus den logischen, ethischen oder ästhetischen Inhalten schöpfen, nehmen an deren transzendentalem Wesen teil, und der einzige Vernunftgrund, der nehmen an deren transzendentalem Wesen teil, und der einzige Vernunftgrund, der
der Religion eigen ist, besteht in dem Postulat, die Totalität aller Vernunftwerte in einer absoluten Einheit zu erleben, die von keiner der Formen unseres Bewußtseins 
In his value-theoretical philosophy of religion, Wilhelm Windelband removed religion from any connection with a particular function of consciousness, referring religion to consciousness as such. After 1900, and under the influence of southwest German neo-Kantianism (especially Heinrich Rickert), Ernst Troeltsch also conceived his philosophy of religion, and above all his philosophy of history. However, Troeltsch did not follow Windelband's philosophy of religion. Admittedly, Troeltsch, like his colleague in Heidelberg, also wishes to demonstrate that religion is based on a transcendental function of consciousness. Yet, beginning in 1904, Troeltsch gives this function the title of a religious a priori (cf. Troeltsch 1922c:24, 1922e:754-768). ${ }^{9}$ With this formulation of the problem, one sees Troeltsch's concern to 'in dem religiösen Bewußtsein das historisch-psychologischkausal bedingte und das aus innerer Notwendigkeit schöpfende, produktive und gültige Wahrheit erzeugende Element gleichzeitig anzuerkennen, zu unterscheiden und zu verbinden' (Troeltsch 1922e:755, cf. 2006:68).

As developed in 1895-1896 in the essay, Die Selbständigkeit des Religion (Troeltsch 2009:364-534), published in the Zeitschrift für Theologie und Kirche, Troeltsch's philosophy of religion orientates itself first around an empirical analysis of religion. This analysis is represented in a historiography of religions which proceeds by means of the psychology of religion. An empirical description and assessment of the religious life, however, does not yet imply anything concerning 'über den Wahrheits- und Realitätsgehalt' of religious phenomena (Troeltsch 1922c:17). The interest in an explanation of religion which is not and cannot be accomplished by means of empirical description leads Troeltsch to supplement the psychology of religion with an epistemology (of Kantian provenance) of the theory of validity (cf. Troeltsch 1904:21154, 1922e:756; cf. also Barth 2005:371-382). Troeltsch is out to combine the empirical study of religion with rational epistemology. Whereas the task of the psychology of religion is to study 'die religiöse Erfahrung ohne Vorurteil für oder wider zu studieren', in order to comprehend 'sie in ihrer charakteristischen Eigentümlichkeit' (Troeltsch 1922c:10, cf. 1922b:364-385, 1922d:492-494), it behoves epistemology to establish the validity and truth of religion by reducing these to a law of reason, in order to secure them 'als gesicherte Wirklichkeit gegen den psychologischen Schein' (Troeltsch 1922c: 22, cf. 1922d:494f.).

Via a modified appropriation of Kant, Troeltsch (1922d) calls this law of reason religious a priori:

Es liegt in der aus dem Wesen der Vernunft heraus zu bewirkenden absoluten Substanzbeziehung, vermöge deren alles Wirkliche und insbesondere alle Werte auf eine absolute Substanz als Ausgangspunkt und Maßstab bezogen werden. Damit ist schon gesagt, daß dieses religiöse Apriori auf den Zusammenhang mit den anderen Apriori angewiesen ist und ihrer inneren Einheit überhaupt erst den festen Substanzgrund gibt. (p. 494f.)

Of course, the religious a priori that is meant to carry the burden of the theoretical validity of the reasoning in erfaßt werden kann.

9. For Troeltsch's philosophy of religion cf. Veauthier (1987:42-63); Barth (2005:359394); Danz (2005a:69-87).
Troeltsch's theory of religion is anything but clear. Two things are obvious: (cf. Troeltsch 1922e:757; cf. Barth 2005:369) by referring religion to a religious a priori, Troeltsch wants to understand religion, as it were, as a phenomenon of the a priori functions of consciousness. Accordingly, religion is a necessary phenomenon of reason, and consequently, not false consciousness as the critique of religion falsely supposes. Thus, religious consciousness is to be understood as consciousness of validity. As a specific consciousness of truth, it originates in the essence of reason. However, the way in which this religious a priori is to be classified within the structure of reason - whether it is on a level with, or still underlies the reason functions of thought, action and feeling (speaking for a moment in the manner of the 18th century) - was left open by Troeltsch. Still more serious: a balancing out of the tension between the transcendental concept of religion as a necessary and legitimate phenomenon of reason, and the idea of God which (since his early works) Troeltsch understands as a consciousness transcending reality (cf. Troeltsch 2009:399, 1922a:301), becomes inconceivable (cf. Barth 2005:370f.).

How then do Tillich's and Otto's theories of religion come to be, within the here outlined context of the historical problem: that is, between 'normal consciousness' and religious a priori?

\section{Between validity and history: The Holy as an interpretive category of the Spirit}

In his discussion of Rudolf Otto's book, The Holy, in the Kant-Studien of 1918, under the title Zur Religionsphilosophie, Troeltsch favourably aligns himself with Otto's overall approach, whilst harshly critiquing the manner in which it is carried through in the particulars, which caught on thereafter. 'Wenn Otto glaubt', thus Troeltsch (2010) summarises the classification of the text from 1917:

die rationalen Elemente in dem ersten Buche [sc. der KantischFries'schen Religionsphilosophie] beschrieben zu haben und nur diese Darstellung jetzt durch die irrationalen zu ,ergänzen', so verdeckt er sich damit m. E. einen totalen Frontwechsel und eben deshalb ist ihm gerade die Hauptaufgabe des Buches, das Verhältnis des Rationalen und Irrationalen zu bestimmen, so wenig gelungen. (p. 425)

However one may judge Troeltsch's discussion, it certainly did not escape his notice that Otto's methodological groundwork of religion as a validity-theoretical a priori departs considerably from his own considerations concerning a transcendental explanation of religion. On the whole, it is quite possible to read Otto's philosophy of religion as an analysis of and counter project to Troetlsch's own, against the backdrop of a shared set of problems. As with Troeltsch, so with Otto the issue is not only to establish the independence of religion between the poles of naturalism and historicism (cf. Otto 1902:483-496, 1903:179-213, 1904:234-272). Also at issue is the interlocking of an explanation of the theoretical validity of religion with a psychology of religion, as well 
as an explanation of the validity of Christianity in the history of religions. In this respect, Otto's and Troeltsch's conceptions belong to the context of the debates concerning self-understanding within the Ritschl School during the first decades of the 20th century. In a way similar to Troeltsch, Otto differentiates between the task of a philosophy of religion which is in keeping with modernity and a psychology of religion and a theoretical philosophy of the validity of religion in the more narrow sense. As undertaken by Otto in the text, Kantisch-Fries'sche Religionsphilosophie, it is incumbent upon him to examine the double task of 'wie Religion und religiöse Überzeugungen und religiöses Erleben im vernünftigen Geiste selber entspringt, aus welchen Vermögen und Anlagen desselben sie hervorgeht und welchen Anspruch auf Gültigkeit sie dadurch hat' (Otto 1909:vi). On the basis of the transcendental explanation of religion, the philosophy of religion must undertake a 'metaphysics of religion' (as Otto - following Kant - calls it) as well as the metaphysical first principles of the theory of religion (Otto 1909:vii). How then, does Otto classify religion within the structure of the spirit, of what does its specific character consist, and in what relation does it stand to the culture functions of the spirit:

Religion ist selber Erleben des Geheimnisses schlechthin; nicht eines Geheimnisses, das nur eins für die Nichteingeweihten wäre, für höhere Grade aber aufgelöst würde, sondern das fühlbare Geheimnis alles zeitlichen Daseins überhaupt und das Durchscheinen der ewigen Wirklichkeit durch den Schleier der Zeitlichkeit für das aufgeschlossene Gemüth. (Otto 1909:75) ${ }^{10}$

According to Otto in his Kantisch-Fries'schen Religionsphilosophie, the specific character of religion results neither from theoretical nor from practical reason - no matter how inevitable and necessary both faculties are for the realisation of religion - but rather from a separate province of the 'Gemüt': from feeling. The concept of feeling already functions here as a 'pre-conceptual evidential experience' (Barth 2003b:43), ${ }^{11}$ which represents the dimension of the unity of the spirit in a way which is conceptually inexpressible. ${ }^{12}$ For this reason, 'Verständnis von Religion und auch von Vorreligion [is] in erster Linie Gefühlsanalyse' (Otto 1910:264). Unlike Schleiermacher (together with Jakob Friedrich Fries and Kant's Critique of Judgement), Otto does not grasp feeling as a pre-reflexive, self-referential state of consciousness (cf. Otto 1909:117, 1922:9-12; cf. Barth 2003b:44). Feeling appertains primarily to a specific way of qualifying consciousness of objects:

10.Cf. also Otto (1910:298): 'Um eine Anlage handelt es sich. Und damit haben wir auch die wirkliche psychologische und zureichende Erklärung für die Tatsache, die wir oben nannten, und auf die wir bei religionsgeschichtlicher Arbeit noch mehr achten müssen als bisher, nämlich, daß es sich im religiösen Werden um einen Trieb handelt und zwar um einen von einer Mächtigkeit wie wenig andere' (cf. also Otto 1910:305)

11.Cf. also Otto (1910:302): “Unter "Gefühl" aber verstehen wir hier, wie auch unsere Sprache selber, einen unausgewickelten, verworrenen und dunklen Vorstellungsinhalt mit einer ihm entsprechenden eigentümlich bestimmten Zuständlichkeit des Gemütes. Jener vermag sich niemals in klare Begriffe aufzulösen. Er heftet sich an Bilder und Vorstellungen, die ihm irgendwie analog sein müssen, ohne daß man angeben kann, worin eigentlich die Analogie besteht und wie weit sie sich erstreckt.

12.Cf. Otto (1909:75): 'Diese Unterordnung geschieht nicht durch einen klaren Mittelbegriff, sondern rein im Gefühl, und zwar in einem begrifflich nicht aufzulosenden Gefühl ("unausgewickelte Begriffe" nach Kant). Ein solches nich begrifflich aussprechbares, nur im Gefühl sich vollziehendes Auffassen nennt unsere Sprache "Ahnen". Daß dieses ahnende Auffassen der Idee aber diesen mächtigen durch alle Grade des Erlebens sich erstreckenden Eindruck auf uns machen kann kommt eben daher, daß die "Idee" im dunklen Innern unseres Geistes immer schon sich "schematisiert" hat, sich belebt hat mit den großen "praktischen" Inhalten, von denen die Rede war.'
Dabei sind es nicht Schlüsse und begriffliche Reflexionen, sondern das unmittelbare Urteilen des Gefühles, das hier einen Vorgang unter die 'Idee' subsumiert. Und daher die unmittelbare Gewalt, mit der beim Erleben des 'Unerklärlichen' der religiöse Schauer den Erlebenden ergreift. (Otto 1909:115)

Thus, one can summarise Otto's considerations in the Kantisch-Fries'schen Religionsphilosophie as follows: religion arises from its own source of reason. In religion concrete, determined consciousness represents the dimension of the unity of consciousness in a preconceived manner, which simultaneously arises as a specific determination of feeling. In his book, Das Heilige (1917), Otto adheres to the methodological basis of the philosophy of religion as extrapolated by him in the Kantisch-Fries'schen Religionsphilosophie as well as in his reception of Wundt's ethnic psychology, which appeared a year later. ${ }^{13}$ Das Heilige also offers a transcendental explanation of religion which relies on Kantian and Friesian critical idealism. Of course, as is evident in the first few methodological chapters of his classic, Otto more sharply emphasised the embeddedness of religion in performance, which is already inherent in the concept of experience, fundamental to his entire theory of religion (cf. Otto 1922:8). One sees therein Otto's concern to intercept the problem of necessary realisation of the functions of consciousness, inherent in the concept of a religious a priori that is, the exclusion of the contingency which is constitutive for the emergence of religion. ${ }^{14}$ The holy, according to the well known determination, is a 'Deutungs- und Bewertungskategorie, die so nur auf religiösem Gebiete vorkommt' (Otto 1922:5). The a priori category of the holy - located in the selfrelation of human consciousness - constitutes the religious sphere. As Otto makes it clear to Wilhelm Wundt, religion is not an epiphenomenon which is derivable from other sources - such as animism - but rather 'Religion fängt mit sich selber an, und ist selber schon in ihren "Vorstufen" des Mythischen und Dämonischen wirkend' (Otto 1922:163). The holy is, indeed, a complex category. It represents a unity-in-tension of irrational and rational moments. Unlike in Troeltsch, the irrational moment does not rest in the 'irrational actuality' of religion (Troeltsch 1922:22). Instead, it belongs, together with the rational elements, to the categorical principles of religion in the self-understanding of the spirit. Hence, Otto takes up the underivable experientiality of religion in its a priori spirit-philosophical groundwork. Religion originates in an underivable way within concrete, determined consciousness of the world, in that 'ich dem Gegenstande ein Prädikat, nämlich ein Bedeutungs-prädikat beilege, das mir die Sinneserfahrung nicht gibt, auch gar nicht geben kann, das ich vielmehr spontan aus eigenem Urteilen ihm beimesse' (Otto 1922:165f.). Religious consciousness articulates itself as an irruption of reflexivity in and upon concrete, determined consciousness, so that the contentual determinations function - by means of the transparency of the spirit with reference to its deep-structure - as representations (or, as Otto calls them, ideograms and schematisations).

13. Concerning the question of continuity in the history of the development of Otto's philosophy of religion cf. Schütte (1969:10); Pfleiderer (1992:108-114).

14.Otto is already aware of this problem in his study of the Kantisch-Fries'sche Religionsphilosophie. Cf. Otto (1909:3f., 1910:305). 
In Das Heilige, Otto (1922) combines his 'geistphilosophische' determination of the specific character of religion with an interpretation of the history of religion, which reaches its summit in Christianity. The point of departure is constituted by the transcendental structure of the spirit:

Die Anlage, die die menschliche Vernunft beim Eintritt der Gattung Mensch in die Geschichte mitbrachte, ward einst auch ihr teils durch Reize von außen teils durch eigenen Druck von innen her zum Triebe, nämlich zum religiösen, der sich in tastender Regung, in suchender Vorstellungs-bildung, in immer vorwärtstreibender Ideen-erzeugung sich über sich selber klar werden will und klar wird durch Auswicklung der dunklen Ideen-grundlage a priori selber, aus dem er auch selber entsprang. (pp. 145, 144)

On the methodological basis of his philosophy of spirit, Otto interprets the history of religion as the spirit's path to self-awareness. ${ }^{15}$ The aim of the processes of the history of religion constitutes the self-transparency of the spirit in its deep structure. To be sure, the numinous, represented in feeling, is to a certain extent the depth dimension of religion. Yet, in its historical development, religion is only able to become a religion of culture and humanity if the two moments of the irrational and rational 'in gesunder und schöner Harmonie stehen' (Otto 1922:173). This is the case with the founding figure of Christianity. For Otto the historical image of Jesus Christ, which for him is 'abhängig von den zufälligen Schwankungen exegetischer Ergebnisse und der Qual historischer Legitimation' (Otto 1922:211), is the expression of the true religion in history. Otto combines transcendental philosophy, the concept of experience, and the history of religion into a tension-laden unity.

\section{From the religious a priori, to intention of the absolute, or: religion and culture in Paul Tillich}

On the basis of a philosophy of spirit, and between the poles of neo-Kantianism and phenomenology, Paul Tillich developed a theory of religion after the First World War which sought both to allow a grasp of the idiosyncrasy of religion as distinct from cultural consciousness, as well as to elaborate on religion's significance for modern culture. This interest of Tillich's is already evident in his dissertation on philosophy, Die religionsgeschichtliche Konstruktion in Schellings positive Philosophie, ihre Voraussetzungen und Prinzipien, submitted at the University of Breslau in 1910 (Tillich 1998:154-272). ${ }^{16}$ The theory of religion outlined here by Tillich refers not only to the contemporary debates of the philosophy of religion, but also claims to overcome the difficulties bound up with current 'concepts of idealistic-history-of-religions', namely those of Ernst Troeltsch (Tillich 1998:158f.).

In the third part of the philosophy dissertation, Tillich (1910) turns his attention to Schelling's concept of religion.

15.Cf. Otto (1922:214): 'Wer Geistes-Geschichte will, muß qualifizierten Geist wollen wer Religions-Geschichte meint, meint Geschichte eines für Religion qualifizierten wer Religion
Geistes.'

16.Concerning the background of Tillich's philosophy dissertation cf. Neugebauer (2007:155-158, 392-399)
In Tillich's judgement, the basic methodological insight of Schelling's later philosophy is that the latter did not postulate a 'selbständiges Apriori für die religiösen Erscheinungen' (Tillich 1998:232). 'Nicht in irgendeiner Form der Geistestätigkeit ist das Wesen der Religion zu suchen, sondern in der Geistigkeit des Menschen als solcher' (Tillich 1998:233). The young Tillich sees Schelling's contribution to the contemporary debates of the philosophy of religion in that the latter constructs the concept of religion on the basis of the concept of God (cf. Tillich 1998:235). Those explanations of religion which reduce religion to a religious a priori, that is, to a specific function of consciousness, are thus eliminated as being inadequate: 'Die reine Substanz des menschlichen Bewußtseins ist das natura sua Gott Setzende: das menschliche Bewußtsein steht in einem realen, substantiellen Verhältnis zu Gott und dies Verhältnis ist das religiöse' (Tillich 1998:235; cf. Neugebauer 2011:41-47, 2007:169-175). ${ }^{17}$

Tillich understands Schelling's speculative philosophy of religion as follows: Schelling integrates the concept of God and the theory of consciousness into a concept of religion, and construes religion as the self-relation of God. The concept of a pure substance of consciousness stands for the synthetic and unifying function in the self-relation of consciousness which already underlies all actions.

Nevertheless, Tillich's reconstruction of Schelling's philosophy of religion is not exhausted through the bringing out of religion as a principle (as he describes it in the previously outlined unifying function). He connects the principle of religion with the question - which goes above and beyond Schelling - as to how religion relates to the functions of consciousness: thinking, action, and feeling. Tillich's specific interest becomes visible in this broadening of the problem: he is not concerned only with the principle of religion, but above all, with the question as to how real and prevailing religion becomes actualised in history (cf. Neugebauer 2011:44). The principle of religion, determined as the pure substance of consciousness, presents the unity function of the human spirit, but can only be realised through the three spirit functions (Geistesfunktionen) of consciousness (cf. Tillich 1998:240f.). Thus, Tillich differentiates the principle of religion from actual, concrete religion. The principle of religion represents the unity function of consciousness, conceived of as God's relation to himself. Concrete religion, by contrast, is the realisation of the unity function in the spirit functions of thought, action, and feeling.

After the First World War, Tillich carried his early theory of religion forward. Nevertheless, it amounts - against the background of his reception of the debates over the theory of sense in neo-Kantianism and phenomenology - not only to a transformation of the principle-theoretical basis of his theory of religion, but also to a new determination of his concept of religion. ${ }^{18}$ In his early theory of religion, Tillich had given up the validity theory concept of a religious a priori, and differentiated it into a perspective of theoretical absoluteness 17.For Schelling's construction of Myth cf. Danz (2005b:28-44).

18.On the debates concerning the theory of sense, from around $1900 \mathrm{cf}$. Barth (2003a:89-123). 
between religion-as-principle on the one hand, and actual religion on the other. Only, his philosophy of spirit - which positions the absolute as the general, basic function of consciousness - is confronted with the objection concerning the manner in which underivability and contingency, which are constitutive for religion, may still be asserted. For, if the absolute represents the basis of all consciousness, and if religion is thought to be the substance of consciousness, how can there be such a thing as unreligious consciousness? Tillich's reformulation of his theory of religion in terms of the theory of sense, and its constitutive distinction between religion-as-principle and actual religion, may be understood to be his way of dealing with this difficulty.

Beginning in 1920, Tillich takes up the determination of actual religion (from the dissertation of 1910) into his formulation of religion as orientation toward the absolute, whilst the former 'religion-as-principle' is transferred to the determination of a substantial or implicit religious consciousness. This determination, which first appears in 1922 in the lecture Die Überwindung des Religionsbegriffs in der Religionsphilosophie (Tillich 2008b:71f.; cf. Wittekind 2011:95-98), aims at the absolute as the universal, basic function in the self-relation of consciousness. Intended, of course, is a description of the presupposition of the synthesis and unity function of consciousness, and not some kind of object-oriented representation of substance. In contrast to substantive religious consciousness, Tillich, via the determination of 'religion as orientation toward the absolute', describes the underivable emergence of religion in history-bound cultural consciousness.

Tillich's reception of Husserl's phenomenology manifests itself in his determination of religion as orientation toward, or intending of the absolute. This alone makes it possible for Tillich to describe more exactly the inner structure of religious consciousness and its relation to cultural consciousness. Tillich not only detaches the concept of religion from the functions of consciousness, but also from the indeterminate concept of experience which constitutes the basis of Otto's theory of religion. ${ }^{19}$ As a component of the theory of religion, the concept of experience is replaced by a description of religious consciousness in terms of the theory of intentionality. Religion is, as Tillich formulates it drawing on the 'concept of intentionality used by the phenomenological school' (Tillich 1999:225), the intention of the absolute. Thus, for Tillich, religion is the event in which history-bound cultural consciousness apprehends itself in its deep structure. This is only possible in and upon the concrete, cultural determinations of consciousness. Tillich's talk, that the absolute is intended by religious consciousness 'through the conditioned representation', describes, in terms of the theory of intentionality, the event of self-transparency in the self-relation of consciousness and its representation. The religious contents do not refer to a dimension external to consciousness, but describe the religious act's transparency

19. Of significance here is Tillich's replacement of the formulation 'Religion is Erfahrung des Unbedingten' with the phenomenologically inspired determination 'Richtung auf das Unbedingte' in the second edition of his lecture, Über die Idee einer Theologie der Kultur von 1921. Cf. Tillich (2008a:30, 41). to itself. The dimension of absoluteness in consciousness can, in a way similar to Otto, only be apprehended in consciousness by way of negation, to the effect that concrete contents become ideograms. It is exactly upon this intentiontheoretical apprehension that Tillich's theory of symbols builds. And, ultimately, Tillich dispels religion as a special sphere of culture and understands it as an event in and upon cultural forms. Religion is the place in culture in which culture becomes comprehensible to itself in its deep structure.

If one glances once more from this result back over the path which our reflections have taken, it becomes evident, that in the debates around 1900, the thought (in terms of the theory of validity) of a religious a priori (as suggested by Ernst Troeltsch and Rudolph Otto) was increasingly problematised and dispelled. As we have seen, Otto himself interlocked the idea of religion, which drew upon necessary a priori functions of consciousness, with the concept of experience in order to preserve the necessary contingency of the concept of religion. Eventually, Paul Tillich totally dismantled the concept of a religious a priori, and construed the theory of religion, in terms of the theory of intentionality, as a description of the religious act in its historical embeddedness. It may remain an open question here, whether Husserl, in the comment mentioned at the beginning, that Otto's work Das Heilige is merely a 'erster Anfang für eine Phänomenologie des Religiösen', aimed at the tension between a religious a priori and the concept of experience. In any case, in the lecture from the winter semester of 1920-1921, his student Martin Heidegger, made a plea for the uncoupling of the concept of religion from the construct of a religious a priori, in order to understand religion as the concrete self-understanding of the human in history.

\section{Acknowledgements}

I express my thanks to Jason Valdez (Vienna) for translating this article.

\section{Competing interests}

The author declares that he has no financial or personal relationship(s) which may have inappropriately influenced him in writing this article.

\section{References}

Barth, U., 2003a, 'Die sinntheoretischen Grundlagen des Religionsbegriffs: Problemgeschichtliche Hintergründe zum frühen Tillich', in Religion in der Moderne, pp. 89-123, Mohr Siebeck, Tübingen.

Barth, U., 2003b, 'Theoriedimensionen des Religionsbegriffs: Die Binnenrelevanz der sogenannten Außenperspektive', in Religion in der Moderne, pp. 29-87, Mohr Siebeck, Tübingen.

Barth, U., 2005, 'Religionsphilosophisches und geschichtsmethodologisches Apriori: Ernst Troeltschs Auseinandersetzung mit Kant', in Gott als Projekt der Vernunft, pp. 359-394, Mohr Siebeck, Tübingen.

Danz, C., 2005a, 'Die geschichtsphilosophische Grundlegung der Theologie bei Ernst Troeltsch', in Gott und die menschliche Freiheit: Studien zum Gottesbegriff in der Neuzeit, pp. 69-87, Neukirchner, Neukirchen-Vluyn.

Danz, C., 2005b, 'Das Werden Gottes im Bewusstsein der Menschheit. Der Begriff des Mythos bei Schelling', in Gott und die menschliche Freiheit: Studien zum Gottesbegriff in der Neuzeit, pp. 28-44, Neukirchner, Neukirchen-Vluyn.

Danz, C., 2009, 'Religion der konkreten Existenz: Heideggers Religionsphilosophie im Kontext von Ernst Troeltsch und Paul Tillich', Kerygma und Dogma 55, 325-341. 
Heidegger, M., 1995a, 'Das Heilige' (Vorarbeiten zur Rezension von Rudolf Otto, Das Heilige, 1917), in Phänomenologie des religiösen Lebens (Gesamtausgabe. II. Abteilung: Vorlesungen, Bd. 60), pp. 332-334, Vittorio Klostermann, Frankfurt a. M.

Heidegger, M., 1995b, Phänomenologie des religiösen Lebens (Gesamtausgabe II, Abteilung: Vorlesungen, Bd. 60), Vittorio Klostermann, Frankfurt a. M.

Heim, K., 1920, 'Ottos Kategorie des Heiligen und der Absolutheitsanspruch des Christentums', Zeitschrift für Theologie und Kirche 28, 14-41.

Neugebauer, G., 2007, Tillichs frühe Christologie: Eine Untersuchung zu Offenbarung und Geschichte bei Paul Tillich vor dem Hintergrund seiner Schellingrezeption, de Gruyter, Berlin.

Neugebauer, G., 2011, 'Die religionsphilosophischen Grundlagen der Kulturtheologie Tillichs vor dem Hintergrund seiner Schelling- und Husserlrezeption', in C. Danz \& W. Schüßler (eds.), Paul Tillichs Theologie der Kultur: Aspekte - Probleme Perspektiven, pp. 38-63, de Gruyter, Berlin.

Otto, R., 1902, 'Darwinismus von heute und Theologie', Theologische Rundschau 5, 483-496.

Otto, R., 1903, 'Die mechanische Lebenstheorie und die Theologie', Zeitschrift für Theologie und Kirche 13, 179-213.

Otto, R., 1904, 'Die Überwindung der mechanistischen Lehre vom Leben in de heutigen Naturwissenschaft', Zeitschrift für Theologie und Kirche 14, 234-272.

Otto, R., 1909, Kantisch-Fries'sche Religionsphilosophie und ihre Anwendung auf die Theologie: Zur Einleitung in die Glaubenslehre für Studenten der Theologie, Moh Siebeck, Tübingen.

Otto, R., 1910, 'Mythus und Religion in Wundts Völkerpsychologie', Theologische Rundschau 13, 251-275.

Otto, R., 1922, Das Heilige: Über das Irrationale in der Idee des Göttlichen und sein Verhältnis zum Rationalen, 8. Aufl., Trewendt und Granier, Breslau.

Pfleiderer, G., 1992, Theologie als Wirklichkeitswissenschaft: Studien zum Religionsbegriff bei Georg Wobbermin, Rudolf Otto und Max Scheler, Mohr Siebeck, Tübingen.

Schütte, H-W., 1969, Religion und Christentum in der Theologie Rudolf Ottos, de Gruyter, Berlin.

Tillich, P., 1998, 'Die religionsgeschichtliche Konstruktion in Schellings positiver Philosophie, ihre Voraussetzungen und Prinzipien', in Frühe Werke, pp. 154-272, de Gruyter, Berlin.

Tillich, P., 1999, Rechtfertigung und Zweifel, in Religion, Kultur, Gesellschaft: Unveröffentlichte Texte aus der deutschen Zeit (1908-1933), 1. Teil, pp. 127-230 de Gruyter, Berlin.

Tillich, P., 2008a, 'Über die Idee einer Theologie der Kultur', in Ausgewählte Texte, pp. 25-41, de Gruyter, Berlin.
Tillich, P., 2008b, 'Die Überwindung des Religionsbegriffs in der Religionsphilosophie', in Ausgewählte Texte, pp. 63-80, de Gruyter, Berlin.

Troeltsch, E., 1904, 'Das Historische in Kants Religionsphilosophie: Zugleich ein Beitrag zu den Untersuchungen über Kants Philosophie der Geschichte', Kant-Studien 9, 21-154. http://dx.doi.org/10.1515/kant.1904.9.1-3.21

Troeltsch, E., 1922a, 'Die christliche Weltanschauung und ihre Gegenströmungen', in Zur religiösen Lage: Religionsphilosophie und Ethik (Gesammelte Schriften, Bd. 2), 2. Aufl., pp. 227-327, Mohr Siebeck, Tübingen.

Troeltsch, E., 1922b, 'Empirismus und Platonismus in der Religionsphilosophie: Zur Erinnerung an William James', in Zur religiösen Lage: Religionsphilosophie und Ethik (Gesammelte Schriften, Bd. 2), 2. Aufl., pp. 364-385, Mohr Siebeck, Tübingen.

Troeltsch, E., 1922c, Psychologie und Erkenntnistheorie in der Religionswissenschaft: Eine Untersuchung über die Bedeutung der Kantischen Religionslehre für die heutige Religionswissenschaft, 2. Aufl., Mohr Siebeck, Tübingen.

Troeltsch, E., 1922d, Wesen der Religion und der Religionswissenschaft, in Zur religiösen Lage: Religionsphilosophie und Ethik (Gesammelte Schriften, Bd. 2), 2. Aufl., pp. 452-499, Mohr Siebeck, Tübingen.

Troeltsch, E., 1922e, Zur Frage des religiösen Apriori: Eine Erwiderung auf die Bemerkungen von Paul Spieß, in Zur religiösen Lage: Religionsphilosophie und Ethik (Gesammelte Schriften, Bd. 2), 2. Auflage, pp. 754-768, Mohr Siebeck, Ethik (Gesam

Troeltsch, E., 2006, 'Ethik und Geschichtsphilosophie', in Fünf Vorträge zu Religion und Geschichtsphilosophie für England und Schottland (KGA Bd. 17), pp. 68-104, de Gruyter, Berlin.

Troeltsch, E., 2009, Schriften zur Theologie und Religionsphilosophie (1888-1902) (KGA, Bd. 1), de Gruyter, Berlin.

Troeltsch, E., 2010, Zur Religionsphilosophie: Rudolf Otto: Das Heilige, in Rezensionen und Kritiken (1915-1923) (KGA, Bd. 13), pp. 412-425, de Gruyter, Berlin.

Veauthier, F.W., 1987, 'Das religiöse Apriori: Zur Ambivalenz von E. Troeltschs Analyse des Vernunftelements in der Religion', Kant-Studien 78, 42-63. http://dx.doi. org/10.1515/kant.1987.78.1-4.42

Windelband, W., 1910-1911, 'Kulturphilosophie und transzendentaler Idealismus', Logos 1, 186-196.

Windelband, W., 1921, 'Das Heilige: Skizze zur Religionsphilosophie', in Präludien: Aufsätze und Reden zur Philosophie und ihrer Geschichte, Bd. 2, 7. u. 8. Aufl., pp. 295-332, Mohr Siebeck, Tübingen.

Wittekind, F., 2011, 'Grund- und Heilsoffenbarung: Zur Ausformung der Christologie Tillichs in der Auseinandersetzung mit Karl Barth', in Jesus of Nazareth and the New Being in History: International Yearbook for Tillich Research, vol. 6, pp 89119, de Gruyter, Berlin. http://dx.doi.org/10.1515/9783110236804.89 